\title{
Surgical Perspective of Wound Site Infection at a Tertiary Care Hospital
}

\author{
Ajaz Ahmad Malik, M.S., ', Shams ul Bari, M.S., ${ }^{2}$ Sajjid H Bhatt, M.S., ${ }^{3}$ M Inam Zaroo M.Ch. ${ }^{4}$ \\ ' Professor, Department of General \& Minimal Invasive Surgery SKIMS \\ ${ }^{2}$ Associate Professor, Department of General Surgery SKIMS MCH \\ ${ }^{3}$ Consultant Surgeon General \& Minimal Invasive Surgery SKIMS \\ ${ }^{4}$ Professor, Department of Plastic Surgery SKIMS
}

Author contributions: Most of the surgeries were performed by Malik A.A and M Inam Zaroo,

Data was compiled and written by Bhatt HS and the manuscript was reviewed and designed by Shams ul Bari.

\section{A B S T R A C T}

\begin{abstract}
Background: Surgical wound infection is a common postoperative complication and causes significant postoperative morbidity and mortality, prolongs hospital stay and adds to hospital costs.

Aims and objectives: This study was designed and carried out in Department of General surgery SKIMS Srinagar in order to find infection rate after clean and clean contaminated surgery in our hospital, to study the clinical profile of patients with surgical site infections (SSI), to find out the common organisms involved in different wound infections and to study the risk factors for postoperative wound Infections.

Methods: This study was carried out prospectively in the Department of General and Minimal Access Surgery SKIMS, Srinagar from February 2012 to January 2014 on 117 cases that underwent clean and clean-contaminated surgery.

Results: In our study the frequency of Surgical Site Infection was $13 \%$. The incidence amongst clean surgical cases was $6.5 \%$ and amongst clean-contaminated cases $19.3 \%$.

Conclusion: Despite prophylactic use of broad spectrum antibiotics and availability of modern surgical and sterilization techniques, postoperative wound infection still remains a major contributory factor of morbidity in patients who underwent surgical procedures. JMS 2018; $21(1): 17-23$

Keywords: Wound infection, antibiotics, cellulitis, abscess, morbidity and mortality.
\end{abstract}

\section{INTRODUCTION}

Surgical site infection is an infection of a wound resulting after an invasive (surgical) procedure. Infection of a surgical wound is a common postoperative complication and has been found to significantly increase postoperative morbidity and mortality. It also prolongs stay in hospital and adds to cost of treatment. Infection of a wound is a result of invasion of tissues by various organisms because of breakdown of local and systemic host defensive mechanisms. In major wound infections there is a discharge of pus from the wound, which may subsequently need an adequate drainage. In addition to discharge of pus major

\section{Correspondence}

Dr. Shams ul Bari, M.S

Associate Professor, Department of General Surgery,

SKIMS Medical College, Bemina, Srinagar

E-mail: shamsulbari@rediffmail.com , wound infections may be associated with various systemic signs. In minor wound infection there is discharge of pus or serous fluid from the wound but no associated systemic signs. $^{[1]}$

Infection of postoperative Wounds is one of the most common factors which delays wound healing. ${ }^{[2]}$ The issue of postoperative wound infection has been there since the time surgery was started as a mode of management. With the advancement in medicine, the prevention and control of this type of infection has become a reality. The addition of antiseptics is considered to be an important mile stone enroute to safe surgery. The discovery and use of the antimicrobial agents has helped the surgeons to perform surgery in many such conditions that were previously thought to be impossible in the pre-antibiotic era due to the risk of infection ${ }^{[3]}$. Infection of a wound is a result of disturbance in host-bacteria equilibrium which creates a 
favourable environment for the growth of bacteria. This not only initiates a systemic septic response but also inhibits the various processes that have a role in the wound healing. All of these processes are affected because of proliferation of bacteria in a wound. ${ }^{[4]}$

Infection of surgical wounds is the second most common nosocomial infection and it is impossible to completely prevent it. $^{[5]}$ It results in patient discomfort, prolongs hospital stay and delays return to routine work. Cost of treatment has been found to increase by $300 \%$ to $400 \%$. ${ }^{[6]}$ Post-operative infections were responsible for $70-80 \%$ of deaths until Ignaz Semmelweis and Joseph Lister, in middle of $19^{\text {th }}$ century, introduced methods of infection control by use of antiseptics. ${ }^{[7]}$

\section{METHODS}

This study was carried out prospectively in the Department of General and Minimal Access Surgery SKIMS, Srinagar from February 2012 to January 2014. All the patients more than 14 years in age who underwent clean and clean contaminated surgery electively were included in the study and the total number of patients was 117. Patients who were excluded from the study included those who refused to participate in the study, those who were already receiving antibiotics for $>1$ week, those who were operated in emergency, those patients undergoing re-operation and those patients who did not report to hospital for follow-up, up to 30 days from the day of operation.

The relevant information of all the patients was entered on a proforma especially designed for the study including bio data, clinical features, possible risk factors, diagnosis, and complications including wound infection, organisms isolated, hospital stay and outcome.

Since this was a descriptive study, therefore no inferential tests were applied. The statistics were reported after calculation by SPSS version 10.0 on computer.

\section{RESULTS}

The total number of patients studied was 117 , which included 81 patients with clean surgery and 36 patients with clean contaminated surgery (Table I and II).The overall frequency of Surgical Site Infection was $13 \%$. The incidence amongst clean surgical cases was 6.5\% (8 out of $81)$ and amongst clean-contaminated cases was $19.3 \%$ (7 out of 36).
Table I: Clean operations performed

\begin{tabular}{|l|l|}
\hline Operation & No. of patients \\
\hline Excision of lipoma & 11 \\
\hline Inguinal Hernia repair & 13 \\
\hline Repair of other Hernias & 7 \\
\hline $\begin{array}{l}\text { Trendelenberg operation for } \\
\text { varicose veins }\end{array}$ & 4 \\
\hline Thyroidectomy & 17 \\
\hline Excision of Breast lump & 6 \\
\hline Mastectomy & 23 \\
\hline Total & $\mathbf{8 1}$ \\
\hline
\end{tabular}

Table II: Clean-contaminated operations performed

\begin{tabular}{|l|l|}
\hline Operation & No. of patients \\
\hline Cholecystectomies & 11 \\
\hline CBD exploration & 9 \\
\hline $\begin{array}{l}\text { Hepatic hydatidosis/cyst } \\
\text { excision }\end{array}$ & 6 \\
\hline $\begin{array}{l}\text { Resection anastomosis of } \\
\text { small bowel }\end{array}$ & 10 \\
\hline Total & $\mathbf{3 6}$ \\
\hline
\end{tabular}

\section{Age \& Sex}

Surgical site infection was seen in $10(15.8 \%)$ out of 63 male patients while as $5(9.3 \%)$ out of 54 female patients had SSI. This suggests that males are more prone to postoperative wound infections than females. As far as age is concerned patients with age more than 50 years were found to be at a greater risk getting for postoperative wound infection (Table III).

Table III: Age Distribution \& Surgical Site Infection

\begin{tabular}{|l|l|l|l|}
\hline Age & $\begin{array}{l}\text { No. of } \\
\text { patients }\end{array}$ & $\begin{array}{l}\text { Patients } \\
\text { with SSI }\end{array}$ & $\mathbf{\%}$ \\
\hline 14-25 years & 19 & 1 & 5.3 \\
\hline 26-40 years & 43 & 6 & 13.9 \\
\hline 41-50 years & 37 & 5 & 13.5 \\
\hline 51-60 years & 18 & 3 & 16.7 \\
\hline
\end{tabular}

\section{Anaemia}

Surgical site infection was found to be more common in patients with a low haemoglobin levels pre-operatively and lower the haemoglobin, more was the incidence of SSI (Table IV). Blood was transfused pre-operatively in all patients with a haemoglobin level of less than $10 \mathrm{gm} / \mathrm{dl}$.

Table IV: Hemoglobin level \& SSI

\begin{tabular}{|l|l|l|l|}
\hline Hb level & $\begin{array}{l}\text { No. of } \\
\text { patients }\end{array}$ & $\begin{array}{l}\text { Patients } \\
\text { with SSI }\end{array}$ & $\%$ \\
\hline$<08$ & 9 & 4 & 44.4 \\
\hline $08-09$ & 18 & 5 & 27.8 \\
\hline $09-10$ & 21 & 2 & 9.5 \\
\hline $10-11$ & 36 & 2 & 5.6 \\
\hline $11-12$ & 16 & 1 & 6.3 \\
\hline$>12$ & 17 & 1 & 5.9 \\
\hline
\end{tabular}




\section{Diabetes}

The number of patients with diabetes in our study was eleven. Among them $5(45.4 \%)$ developed surgical site infection. On the other hand, only $10(9.4 \%)$ of the 106 nondiabetic patients developed postoperative surgical site infection. This supports the fact that diabetes mellitus is a risk for developing surgical site infection.

\section{Smoking}

The total number of patients with history of smoking was 17. Out of them $6(35.2 \%)$ developed SSI. In contrast to it, out of the 100 non-smoker patients, only $9(9 \%)$ developed the surgical site infection.

\section{Duration of Operation}

Most of the surgical procedures were completed within 60 minutes. The rate of the surgical site infection was more in those surgical procedures that lasted more than 150 minutes (Table V).

Table V: Duration of Surgery \& Surgical Site Infection

\begin{tabular}{|l|l|l|l|}
$\begin{array}{l}\text { Operation } \\
\text { time }\end{array}$ & $\begin{array}{l}\text { No. of } \\
\text { patients }\end{array}$ & $\begin{array}{l}\text { Patients } \\
\text { with SSI }\end{array}$ & $\%$ \\
\hline$<30 \mathrm{mins}$ & 29 & 1 & 3.4 \\
\hline $31-60 \mathrm{mins}$ & 45 & 2 & 4.4 \\
\hline $61-90 \mathrm{mins}$ & 25 & 4 & 16 \\
\hline $91-150 \mathrm{mins}$ & 12 & 3 & 25 \\
\hline$>150 \mathrm{mins}$ & 14 & 5 & 35.7 \\
\hline
\end{tabular}

\section{Total leukocyte count:}

The total leukocyte count (TLC) of more than $8000 / \mathrm{mm}^{3}$ was noted in 15 cases with SSI (Table VI).

Table VI: Total Leucocyte Count in patients with Surgical Site Infection

\begin{tabular}{|l|l|l|}
\hline Total leucocyte count & $\begin{array}{l}\text { No. of } \\
\text { patients }\end{array}$ & $\%$ \\
\hline$<8000 / \mathrm{mm} 3$ & 3 & 20 \\
\hline $8000-11000 / \mathrm{mm} 3$ & 2 & 13.3 \\
\hline $11000-15000 / \mathrm{mm} 3$ & 7 & 46.7 \\
\hline $15000-20000 / \mathrm{mm} 3$ & 3 & 20 \\
\hline
\end{tabular}

\section{Seniority of Surgeons and Sequence number of patients} on an operation table

During our study we noted that the chances of surgical site infections were less when patients were operated as the first case on a particular operation table (Table VII). Our study also highlighted the fact that the experience of the operating surgeon affects the outcome and we found that the rate of infection was higher in patients who were operated by less experienced surgeons (Table VIII).
Table VII: Incidence of SSI according to sequence of patients on operation table

\begin{tabular}{|l|l|l|l|}
\hline $\begin{array}{l}\text { Sequence } \\
\text { of patients }\end{array}$ & $\begin{array}{l}\text { No. of } \\
\text { patients }\end{array}$ & $\begin{array}{l}\text { Patients } \\
\text { with SSI }\end{array}$ & $\mathbf{\%}$ \\
\hline Patient 1 & 51 & 5 & 9.8 \\
\hline Patient 2 & 47 & 7 & 14.9 \\
\hline Patient 3 & 19 & 3 & 15.8 \\
\hline
\end{tabular}

Table VIII: Seniority of Operating Surgeon and Surgical Site Infection

\begin{tabular}{|l|l|l|l|}
\hline $\begin{array}{l}\text { Surgeon } \\
\text { category }\end{array}$ & $\begin{array}{l}\text { No. of } \\
\text { patients }\end{array}$ & $\begin{array}{l}\text { Patients } \\
\text { with SSI }\end{array}$ & $\%$ \\
\hline A & 30 & 3 & 10 \\
\hline B & 29 & 3 & 10.3 \\
\hline C & 41 & 5 & 12.1 \\
\hline D & 17 & 4 & 23.5 \\
\hline
\end{tabular}

Category- $\mathrm{A}=\mathrm{Consultants}$ with surgical experience of more than 10 years. (Professors and Associate Professors)

Category- $\mathrm{B}=$ Consultants with surgical experience of more than 5 years. (Assistant Professors and Senior Registrars)

Category- $\mathrm{C}=$ Senior Residents.

Category-D=Post graduates students.

\section{Clinical Features of Wound Infection:}

The presentation of wound infection and the common organisms responsible for infection are given in Table IX. As a matter of routine, the first wound dressing was changed on the $3 \mathrm{rd}$ postoperative day. In patients who complained of fever, severe pain in the wound and those where the dressing was soaked, dressings pads were changed more frequently. Most of the patients presented within three weeks after surgery although one patient presented in the fourth postoperative week (Table X). Wound dehiscence was seen in the second post-operative week. None of our patients developed septicaemia or any other life threatening condition.

Table IX: Type of Surgical Site Infection \& Organisms

\begin{tabular}{|l|l|l|l|}
\hline $\begin{array}{l}\text { Surgical site } \\
\text { infection }\end{array}$ & $\begin{array}{l}\text { Common } \\
\text { organism }\end{array}$ & $\begin{array}{l}\text { No. of } \\
\text { patients }\end{array}$ & $\%$ \\
\hline Wound abscess & $\begin{array}{l}\text { Staphylococcus } \\
\text { aureus }\end{array}$ & 7 & 46.7 \\
\hline $\begin{array}{l}\text { Localized } \\
\text { cellulitis }\end{array}$ & $\begin{array}{l}\text { Escherichia } \\
\text { coli }\end{array}$ & 3 & 20 \\
\hline $\begin{array}{l}\text { Spreading } \\
\text { cellulitis }\end{array}$ & $\begin{array}{l}\text { Streptococcus } \\
\text { pyogenes }\end{array}$ & 2 & 13.3 \\
\hline $\begin{array}{l}\text { Wound } \\
\text { dehiscence }\end{array}$ & $\begin{array}{l}\text { E.Coli+Klebsie } \\
\text { lla/Pseudomon } \\
\text { as }\end{array}$ & 3 & 20 \\
\hline
\end{tabular}


Table X: Time of Presentation of Surgical Site Infection

\begin{tabular}{|l|l|l|}
\hline Time of presentation of SSI & $\begin{array}{l}\text { No. of } \\
\text { patients }\end{array}$ & $\%$ \\
\hline $\begin{array}{l}\text { Before first dressing with } \\
\text { fever>99.6oF or pain in the } \\
\text { wound }\end{array}$ & 2 & 13.3 \\
\hline $\begin{array}{l}\text { Abscess, cellulitis or } \\
\text { discharge noted at 1st week } \\
\text { postoperatively }\end{array}$ & 4 & 26.7 \\
\hline $\begin{array}{l}\text { Abscess, cellulitis or } \\
\text { discharge noted at 2nd week } \\
\text { postoperatively }\end{array}$ & 6 & 40 \\
\hline $\begin{array}{l}\text { Abscess, cellulitis or } \\
\text { discharge noted at 3rd week } \\
\text { postoperatively }\end{array}$ & 2 & 13.3 \\
\hline $\begin{array}{l}\text { Abscess, cellulitis or } \\
\text { discharge noted at 4th week } \\
\text { postoperatively }\end{array}$ & 1 & 6.7 \\
\hline
\end{tabular}

\section{Results of Culture taken from the Wound:}

The commonest bacteria isolated from infected wounds after culture were Staphylococcus aureus, Escherchi coli, Klebsiella, Pseudomonas and Streptococci. Staphylococcus aureus was found to be resistant to penicillin and cotrimoxazole but sensitive to co-amoxiclav and cefuroxime.

\section{Postoperative Hospital Stay:}

Patients with minor wound infections were managed conservatively. Out of the 15 patients six patients initially received medication. Two of such patients developed suppuration later on and needed drainage of pus. The rest of nine patients had pus formation which were laid open after removal of sutures. Wound swabs were taken from all these wounds and sent to the laboratory for culture and sensitivity and antibiotics were changed on the basis of culture. The wounds were dressed twice a day with povidine soaked gauze packs. Thus total of eleven patients underwent some type of surgical intervention. There was no mortality in our study.

The hospital stay was delayed in all the patients with wound infection. Patients with localized cellulitis were managed with oral antibiotics only. However patients with an abscess formation were taken for surgical drainage and these patients remained in the ward for more than the expected duration. Eight of such patients stayed in the hospital for 2-5 days, four patients for 5-10 days and three of them stayed for 10 - 20 days.

\section{DISCUSSION}

Surgical site infections are associated with considerable morbidity and can have a significant effect on quality of life. The hospital stay gets extended which results in a considerable financial burden to healthcare providers. With the advances in surgery and anaesthesia it has become possible to operate patients who are at greater risk of surgical site infections. In addition, large numbers of infections are now being seen in primary care because of early discharge of patients from the hospitals following day care and fast-track surgery.

The rate of surgical site infection varies from country to country, from area to area and even from hospital to hospital. In our study the overall incidence of infection was $13 \%$, where as Damani described a 30\% incidence of hospital-acquired infection. Holtz et al has reported a $40 \%$ incidence of hospital acquired infections in all clean and clean contaminated procedures, with the resultant increase in health care cost and morbidity of the patients ${ }^{[8]}$.In our study the postoperative wound infection rate was $6.5 \%$ amongst clean cases, which is higher as the usually reported rates vary from $1 \%$ to $4 \%$, although most of the studies document a rate of less than $2 \%{ }^{[9]}$. In our study rate of infection for clean-contaminated cases was $19.4 \%$ while as other studies have documented infection in such cases in the range of $5-30 \%{ }^{[10]}$. In another study conducted at Mayo Hospital, Lahore an infection rate of $5.05 \%$ in clean and $8.39 \%$ amongst clean-contaminated cases was reported ${ }^{[11]}$. Hernandez K et al from Peru in 2005 described rates of $13.9 \%$ and $15.9 \%$ amongst clean and clean-contaminated cases respectively ${ }^{[12]}$.

A dose of prophylactic antibiotic (ceftriaxone and sulbactum) was received by all the patients who had to undergo clean surgery, at the time of induction of anaesthesia. Single dose prophylactic antibiotic therapy is a recommended in clean cases ${ }^{[13]}$. This practice is efficient, cost effective and prevents the emergence of nosocomial infections in a developing country such as India with extremely limited health care resources. Clean procedures constitute approximately 60 percent of all surgical procedures and it is estimated that prophylaxis for clean procedures would reduce the overall incidence of wound infection markedly. ${ }^{[13]}$

There are concerns that different sources of clinical data such as medical record review, patient report, or surgeon report may yield different SSI rates ${ }^{[14-18]}$. A review was conducted recently which compared the CDC-National 
Healthcare Surveillance Network (CDC/NHSN) with the American College of Surgeons National Surgical Quality Improvement Project (ACS-NSQIP).They found an average difference of $8.3 \%$ in SSI rates within the same hospitals. ${ }^{[19-20]}$ Despite this potential source of variability, the CDC/NHSN program allows for significant variability and discretion in the surveillance methodology used to determine the SSI rate. This puts a question on the validity of the data when comparing SSI rates across health-care facilities

In our study, we observed that patients with age of more than 50 years had a higher incidence $(16.7 \%)$ of postoperative wound infection as compared to $5.3 \%$ in patients with age less than 26 years (Table III). For surgical wound infections an odd ratio of 1.2 for every 10 years of age was observed in our study. ${ }^{[21]}$ It can be because of multiple factors like malnutrition, malabsorption, delayed healing rates, increased catabolic processes and immunodeficiency ${ }^{[22]}$.

Although anaemia as such is not considered as an established factor for postoperative wound infection but a higher incidence of postoperative wound infection was noted in patients with initial decreased haemoglobin level (Table V). However, this may be the result of blood transfusions, given preoperatively to bring the haemoglobin level up to $10 \mathrm{gm} / \mathrm{dl}$ as has been postulated by Ford CD et $\mathrm{al}^{[23]}$ in 1993.

In our study, more than $80 \%$ patients presented to us with surgical site infection within three weeks of postoperative period. This is in agreement with the study conducted by Twun DK et al who reported that $92 \%$ of the postoperative wound infections were detected by the 21 st day ${ }^{[24]}$. On the other hand study conducted at Fauji Foundation Hospital, Rawalpindi, most cases of wound infection were noticed by the 6 th postoperative day ${ }^{[25]}$.

It is an established fact that diabetic patients are at higher risk for getting infections ${ }^{[26]}$. During our study we noted that the rate of postoperative wound infection in diabetic patients was $45.4 \%$, which is significantly higher, despite the fact that sugar levels were controlled before surgery. In our study increased rate of surgical site infection (35.2\%) was also noted amongst smokers. This is comparable to several studies which have also shown a higher incidence of wound infection amongst smokers than in non-smokers. Smoking has a detrimental effect on the tissue oxygenation, thereby delaying processes of wound healing and hampering the neutrophil defensive mechanism against pathogens ${ }^{[27]}$.

The experience of the surgeon has also bearing on the incidence of postoperative wound infection as was noted in our study. We observed that the rate of postoperative wound infection was higher amongst patients operated by junior surgeons $(23.5 \%)$ with lesser experience than those operated by senior surgeons $(10 \%)$ with more experience as depicted in Table IX. Mishriki OF et al reported that the rate of infection was higher in view of increased duration of operation in surgeries performed by junior residents. The rates of infection with individual surgeons varied from 3.9 to $14.6 \%{ }^{[28]}$.

An interesting observation was that the rate of infection was significantly low in those patients who were operated as first case on a particular table. It was $9.8 \%$ for patients operated as first case, $14.9 \%$ as second case, and $15.8 \%$ as third case. This is in agreement with the observation ${ }^{[28]}$ who also observed that rate of wound infection was higher in cases who were $2^{\text {nd }}$ or $3^{\text {rd }}$ in order for surgery. This may be due to some break in the sterility of the operation room or instruments as the number of micro flora of the OT environment increase because of persistent movement of the OT staff and the surgical team, besides the fact that senior surgeons usually perform first cases.

Prolonged time is a significant risk factor for postoperative wound infection. ${ }^{[28]}$ and more the duration of surgery more are the chances of wound infection. In our study, we observed a higher incidence of postoperative wound infection when duration of operation was more than 150 minutes.

Abscess formation was the most common presentation in our cases. In literature, wound infection has been reported as the commonest cause of dehiscence, although only 3 cases were seen in our series.In our study we did not come across any case of septicaemia, spreading cellulitis or necrotizing fascitis. Although, a positive culture is not necessary for the diagnosis of wound infection ${ }^{[29]}$ however, all our cases were cultured and reported positive. Arora $\mathrm{S}$ et $\mathrm{al}^{[31]}$ have reported a figure of $87 \%$ for positive cultures.

As reported by most of the studies ${ }^{[23-25]}$ Staphylococcus aureus has been described single most common pathogen involved in postoperative wound infections. During our 
study, $45 \%$ cultures grew staphylococcus aureus, and was sensitive to cefuroxime and co-amoxiclav. E.coli was the second followed by Klebsiella as the third most common pathogen. Most of the Gram+ve organisms were sensitive to amoxicillin, co-amoxiclav, cefuroxime and amikacin ${ }^{[3]]}$.

In our study the average postoperative hospital stay was five days in uncomplicated cases and 15 days in those with wound infection (range 8-25 days). Kastpibal $\mathrm{N}$ et al ${ }^{[32]}$ reported that the recovery of patients is delayed by about one week and the hospital stay is prolonged significantly in patients with wound infection. We did not estimate the cost on wound infection in our study but was obviously higher.

\section{CONCLUSION}

Postoperative wound infection is a major factor that contributes to patient morbidity despite modern surgical and sterilization techniques and prophylactic use of good antibiotics. The overall postoperative wound infection rate of $13 \%$ is acceptable but more attention is required in clean surgical procedures where the rate is around $6 \%$, although the universally acceptable rate is less than $2 \%$. This can be achieved by taking various appropriate steps to improve sterility of our operation theatres, ward environment and methods of sterilization. The common correctable risk factors such as malnutrition, obesity, presence of infective foci, diabetes and unhygienic conditions should be taken care of. This will save the economic burden on the patient, hospital and the community as a whole. There should be no injudicious, improper and prolonged use of antibiotics to avoid development of resistant strains of micro-organisms.

\section{REFERENCES}

1. Leaper DJ. Wound Infection. In: Russell RCG, William NS, Bulstrode CJK, eds. Bailey \& Love's Short Practice of Surgery; 24th ed. London: Arnold; 2004.p.118-132.

2. Nicholas RL. Wound Infection rates following clean operative procedures: Can assume them below? (Editorial).Infect Cont Hosp Epidemiol 1992: 13: 45 . [ P M I D : 1517543 D O I : ] http://dx.doi.org/10.2307/30145258 http://dx.doi.org/10.1086/646572

3. Pea F, Viale P, Furlaunt MI. Antimicrobial agents in elective surgery: Prophylaxis or early therapy? J Chemotherap 2003 Feb; 15(1): 3-11.PMID ; 12678408.

4. Robson MC. Wound Infection. A failure of wound healing caused by an imbalance of bacteria. Surg Clin North Am 1997 Jun; 77(3): 637-50. http://dx.doi.org/10.1016/S0039-6109(05)70572-7

5. Martone WJ, Garner JS. Proceedings of the 3rd Decennial International conference on Nosocomial Infections. Am J Med 1991; 91(3): S1-S3. http://dx.doi.org/10.1016/0002-9343(91)90334-T.

6. Steven $M$, Steinberg $J$, et al. Investigation and Treatment of Surgical infection. In: Cuscheri A, Steele RJC, Moossa AR, eds. Essential Surgical Practice, 3rd ed. London: Butterworth Heinemann;1995. p.20.

7. Meghraj Chawada, Shobha S. Nisale, Ganesh K. Kharkate, Sudhir B. Deshmukh. The incidence of postoperative infection in tertiary rural hospital.International surgery journal. Vol 4, No 5 (2017)

8. Holtz TH, Wenzel RP. Post-discharge surveillance for Nosocomial Wound Infection. A brief review \& commentary. Am J Infect Cont 1992; 20: 20613.doi.org/10.1016/S0196-6553(05)80148-8

9. Ojiegbe GC, Njoku Obi AN, Ojukwu JO. Incidence and parametric determinants of Postoperative Wound Infection in university teaching hospital. Cent Afr J M e d $1990 \quad$ M a r ; $36: 63-7$. PMid:2225020

10. Wilson AP, Weavill C, Burridge J, Kelsey MC. The use of wound scoring method 'ASEPSIS' in postop. wound surveillance. J Hosp Infect 1990; 16(4): 309. http://dx.doi.org/10.1016/0195-6701(90)90002-6

11. Akhtar S, Gondal KM, Ahmed M, Mohammad Y, Goraya AR, Karim K, Chaudhry AM. Surgical Wound Site Infection-Our experience. Ann King Edward Med Coll 2001 Sept; 7(3): 211-2.

12. Hernandez K, Ramos E, Seas C, Henostroza G, Gotuzzo E. Incidence of and risk factors for Surgical Site Infection in a Peruvian hospital. Infect Control Hosp Epidemiol 2005 May; 26(5): 473-7. http://dx.doi.org/10.1086/502570 PMid:15954486

13. Yousuf M, Hussain M. Need and duration of Antibiotic therapy in Clean and Clean-contaminated Operations. J Pak Med Assoc 2002 July; 52(7): 284-6. PMid:12481657

14. Surgical site infection: comparing surgeon versus 
patient self-report Julius CuongPham, MD, PhD,a, * Melinda J. Ashton, MD,b Chieko Kimata, PhD, MPH, MBA,b Della M. Lin, MD, MS, cand Beau K. Nakamoto, MD. J Surg Res. 2016 May 1;202(1): 95102. PMCID: PMC5642958.

15. LaPar DJ, Isbell JM, Kern JA, Ailawadi G, Kron IL. Surgical Care Improvement Project measure for postoperative glucose control should not be used as a measure of quality after cardiac surgery. J Thorac Cardiovasc Surg. 2014;147:1041. [PubMed]

16. Rasouli MR, Jaberi MM, Hozack WJ, Parvizi J, Rothman RH. Surgical care improvement project (SCIP): has its mission succeeded? J Arthroplasty. 2013;28:1072. [PubMed]

17. Tillman M, Wehbe-Janek H, Hodges B, Smythe WR, Papaconstantinou HT. Surgical care improvement project and surgical site infections: can integration in the surgical safety checklist improve quality performance and clinical outcomes? J Surg Res. 2013;184:150. [PubMed.

18. Pham JC, Frick KD, Pronovost PJ. Why don't we know whether care is safe? Am J Med Qual. 2013;28:457. [PubMed]

19. CDC; Operational guidance for reporting surgical site infection (SSI) data to CDC's NHN for the purpose of fulfilling CMS's hospital inpatient quality Reporting (IQR) Program Requirements. Control CfD, editor. 2012 Available from:

20. CMS. Fact sheets: CMS to improve quality of care during hospital inpatient stays. Baltimore, Maryland: CMS; 2014.

21. Lizan-Garcia M, Garcia-Caballero J, Asensio-Vegas A. Risk factors for Surgical Wound Infection in general surgery: A prospective study. Infect Control Hosp Epidemiol 1997 May; 18(5): $310-5$. http://dx.doi.org/10.2307/30141223;PMid:9154472

22. Mark RM, Edwin AD. Nutrition and Infection. Surg Clin North Am 1994 June; 74: 659-664.
23. Ford CD, Van Moorleghem G, Menlove RL. Blood transfusion and Postoperative Wound Infection. Surgery 1993 June; 113: 607.

24. Twun DK, Grant G, Al-Suleiman SA. Microbiology of Postoperative Wound Infection. A prospective study of 1770 wounds. J Hosp Infect 1992; 21: 29. http://dx.doi.org/10.1016/0195-6701(92)90151-B

25. Abbasi AA, Chaudhry IA. Prophylactic antibiotics in clean surgical wounds. Rawal Med J 2003 Jun; 28 (1): 2-6.

26. Colin J. Diabetic skin and soft tissue Infections. Current opinion. Infec Dis 1994; 7: 215.

27. Sorensen LT, Karlsmark T, Gottrup F. Abstinence from smoking reduces Incisional Wound Infection: A randomized controlled trial. Ann Surg 2003; 238:1-5. http://dx.doi.org/10.1097/01.SLA.0000074980.3970. 31 PMid:12832959 PMCid:PMC1422652

28. Mishriki OF, Law DJ, Johnson MG. Surgical audit. Variations in Wound Infection rates of individual surgeons. J R Coll Surg Edin 1991; 36: 251-53. PMid:1941743

29. Eltahawy AT, Mokhtar AA, Khalaf RM, Bahnassy AA. Postoperative Wound Infection at a university hospital in Jeddah, Saudi Arabia. J Hosp Infect 1992 May; 21: 79-83.http://dx.doi.org/10.1016/01956701(92)90156-G

30. Hackam DJ, Robstein OD. Stoma closure and Wound Infection. An evaluation of risk factors. Can J Surg 1995; 38(2): 148 .

31. Arora S, Prabhakar H, Garg BB, Jindal N. Anaerobic bacterial flora of Wound Sepsis. J Indian Med Assoc 1990 Jun; 88: 154-6. P Mid: 2230157

32. Kasatpibal N, Thongpiyapoom S, Narong MN, Suwalak N, Jamulitrat S. Extra charge and extra length of Postoperative Stay attributable to Surgical Site Infection in six selected operations. J Med Assoc Thai 2005; 88(8): 1083-91. PMid:16404836 